\title{
Enterprise's process innovations in the context of enterprise's financial performance
}

\author{
Marianna Kicová \\ University of Economics in Bratislava, Faculty of Economic Informatics, Bratislava, Slovakia
}

\begin{abstract}
Enterprise process management is one of the most important components of enterprise management. It is necessary to know, optimize and innovate the ongoing processes in the enterprise in order to efficiently meet the established results of the enterprise in order to enhance the efficiency of the enterprise's processes themselves and satisfy the customers' requirements in the context of the financial performance enhancement and competitiveness of the enterprise. The enterprise's financial performance is measured as the rate of achievement of the enterprise's financial performance by comparing actual and established results. In assessing the performance of ongoing processes in the enterprise, it is necessary to establish procedures that provide objective information on ongoing processes in the enterprise. The aim of the paper is to analyze enterprise's process innovations in the context of enterprise's financial performance enhancement and to assess opportunities to develop these processes as fundamental aspects of measurement and enhancement of the enterprise's financial performance. The result of the research is that the implementation of enterprise's process innovations has a significant impact on enhancing the enterprise's financial performance, assuming optimal control and coordination of all ongoing activities in the innovation process.
\end{abstract}

\section{Keywords}

Innovation, Process Innovation, Financial Performance, Enterprise.

\section{Introduction}

Nowadays, the foundation of the enterprise's success is to move from a functional organization to a process organization. Processes are an essential part of the enterprise as well as the whole society. Every enterprise wants to meet its aims, and this is not possible without knowing the processes. It means adapting enterprise's processes to meet customer requirements while eliminating redundancies and deficiencies from enterprise's processes. Process management is one of the most important parts of enterprise's management. In the knowledge-based economy, innovation is at the forefront, virtually ubiquitous, and applies to all areas of the enterprise. Innovation becomes the philosophy of the future. Innovation is the ability to come up with new, innovative ideas, combining or combining them in a unique way. Innovation in the enterprise's supports the preconditions for new practices and solutions (Lesáková, 2008). Innovative processes bring enterprise's success. They are a decisive tool for economic development of the enterprise. An important factor in the enterprise's innovation is high performance, flexibility and the development of innovation potential (Dugas \& Ferencz, 2015). We distinguish innovation management from innovative management. Innovative management refers to the management of which the adoption of innovation, the promotion of new, creative solutions is the basis of management methods and techniques. It assumes the creativity of human resources in the enterprise, the introduction of new, radical methods and techniques of human development, the introduction of knowledge management, as well as pro-innovation behavior. The innovative approach of the enterprise's results in an improved 
and changed new solution. We know innovation management as a separate management discipline, which deals with the methods and techniques of managing the innovation process in the enterprise, up to their successful implementation on the market. Innovation management is a comprehensive management tool for effective innovation management (Lesáková, 2008). Innovation Management is a new management discipline that deals with identifying, analyzing and managing the entire innovation process (Dugas \& Ferencz, 2015). Enterprises are going through different changes and managers need to be ready. Changes are seen by enterprise's managers as opportunities or perceived as threats (Drucker, 2007). Schumpeter \& Swedberg (1989) has characterized 5 specific changes that evolve introducing new products or original products with new features, opening new markets, changes in production organization and security, the use of new production techniques, production processes or new commercial production security, and the use of new raw materials or semi-finished products. The enterprise that seeks to maintain and consolidate its market position must pursue an innovative policy that will enable it to achieve a competitive position and competitive advantage (Synek, 1996).

The aim of the paper is to analyze enterprise's process innovations in the context of enterprise's financial performance enhancement and to assess opportunities to develop these processes as fundamental aspects of measurement and enhancement of the enterprise's financial performance.

\section{Literature review}

The founder of the theory of innovation is Joseph Schumpeter, who in 1911 formulated the "Combinations of developmental changes", understood as overcoming the restoration of systems and processes in a closed circle (Schumpeter \& Swedberg, 1989). He focused on analyzing the enterprises' conditions under which an enterprise is interested or can make new combinations of developmental changes. $\mathrm{He}$ understood innovation as the application of these changes in the enterprise's practical activities. Innovation is the most important factor determining enterprise's success. With increasing globalization and increased competition, they are becoming increasingly important. Innovation must combine business, marketing, development, production, resource and enterprises' processes.
Their success is not based on the random search for "miraculous" solutions, but is based on the knowledge of the system, psychology, philosophy and innovation economy (Kislingerová, 2008). According to Drucker (2007), innovation is a specific tool for entrepreneurs to use change as an opportunity to differentiate their entrepreneurship. Freeman (2008) describes innovation as the design, producing, technical, marketing and management activities associated with launching a new product or first commercially using a new process or device. Innovation comes from the Latin word "Innovare" that means renewing, changing, making new. We define the nature of innovation as a process from creating an idea to accepting change, radical change, creating an invention or something new to the whole of society. Overall, innovation is a purposeful, dynamic process that results in a positive change aimed at improving the enterprise's reproduction process and greater customer satisfaction (Čimo \& Mariaš, 2006). There is no need to look only for technical breakthroughs under innovation. Technical changes to the product and technological lead in production may not be successful. Many enterprises have perfect products made by professional technology, but customers are not interested. What distinguishes innovation from normal conversion is creating value for the customer. Innovation brings value to the customer in the form of simplicity, reduced risk, increased comfort, convenience, benefit of entertainment, price, image, fashion, emotion or environmental friendliness (Kislingerová, 2008). Changes in decisions may not always produce a positive result, but the rigid behavior of the enterprise certainly does not contribute to its growth. Enterprises consider sustainable production as a means of creating innovation, considering environmental, economic, and social considerations (Germani, Luzi, Marilungo, Papetti, \& Peruzzini, 2016). Only enterprise that knows its customers well can understand their needs, requirements and motives. Given that customers and competitors are constantly moving, success can only be achieved by the enterprise that understands this move and can create a new, customized offer accordingly (Kislingerová, 2008). Innovation is a strategyoriented change that brings benefits to customers and a blue ocean enterprise (Chan Kim \& Mauborgne, 2015).

Innovation promotes creativity and invention. The main reason for innovation is usually a group of customers, or research results that lead to the innovations of product, innovations of processes, 
innovation of enterprise's system, and innovation of enterprise. Innovation also includes modernization. Enterprise's innovations have two forms, such as process innovations that deal with streamlining technological processes, and product innovations that deal with creating completely new products or increasing the economic and technical parameters of current products. Innovations in the launch of new products on the market can bring many benefits to the enterprise, such as gaining a positive image in the eyes of the public, obtaining a favorable position on the market early, choosing distribution channels, gaining quickly through low production costs (Synek, 1996). Innovation can relate to products, means of production, technology, organizational structure of the enterprise, qualification and professional structure of the workforce. These can be both quantitative and qualitative changes, changes with both positive and negative socio-economic consequences (Čimo \& Mariaš, 2006). Enterprises can support the competitiveness of the products capabilities to develop organizational strategies that support technological innovation (Liu \& Jiang, 2016). Kislingerová (2008) distinguishes these types of innovations:

- Product innovations that introducing new or significantly improved products or services, for example significant improvement in technical parameters, significant changes in product and service capabilities. These innovations lead to the launch of a brand-new product or service or to a significant improvement of an existing product.

- Process innovation such as changes in production and supply methods, introduction of new or significantly improved production or delivery methods, for example significant changes in technology, equipment, or software.

- Marketing innovations that introducing a new marketing method and includes significant changes in product design or packaging, product placement, product support, or awards. These innovations can include changes in the marketing mix, product design, packaging, product promotion and placement, as well as changes in pricing and service methods.

- Organizational innovation that introducing a new organizational method in enterprise's practices, in a job organization or in external relationships.
According to (Kislingerová, 2008) innovations offer some benefits. An enterprise coming first has the chance of high profits, if it comes with groundbreaking technology, it can destroy the benefits of another enterprise. Innovation should be considered comprehensively. Technologies are not the only form of innovation, new ways of doing business can be a major innovation. They can become an important competitive advantage, not easily replicable. The inclination to innovate employees, managers, owners of small and medium-sized enterprises tend to be more innovative and bolder than in large enterprises. In fact, many small and medium-sized enterprises arise because the former employees of large corporations were not satisfied to push for innovation. Successful innovation is conditional on a comprehensive approach; it must note a whole range of enterprise's activities such as purchasing, management, marketing, technology, organization, service and sales. The focus must be on customer management and implementation. In the last stage, it must derive the appropriate effect from innovation. Customer decides on success, respectively failure of some innovation.

The term process refers to any activity in which inputs arrive and is output in a certain way. In a simple sense, it means transforming inputs into outputs. Often the output from one process directly enters the next following process (Borovský, 2005). A process is a group of activities and activities that are interconnected, require one or more inputs, and produce an output that has value for the customer in the form of a product or service. In addition to inputs, the process enters resources such as human (workers) and physical (machines, equipment, tools, auxiliary materials, etc.). Each process has its internal and external limitations. The process is defined as interconnected activities that transform inputs into outputs in their sequence. It means a summary of activities that require one or more types of inputs and produces an output that is worth the customer. The aim of the process is to create a performance that is required by an internal or external customer (Papulová, Papula, \& Oborilová, 2014). There are main processes (key, implementation, value-creating), supporting processes (provisioning, support) and managerial processes.

The main processes affect the product of the enterprise, they are directly involved in the creation of value, they are the most perceived by the customer. They are key to the enterprise, fulfill mission and answer basic existential questions. 
Supporting processes are activities necessary for the operation of the main processes, but do not create value from the perspective of the customer. They are indirectly involved in creating value for the customer. They indirectly support the fulfillment of the enterprise's basic mission. These include purchase, maintenance, energy supply, warehouse management, etc. Management processes manage and coordinate core and support processes as well as the entire enterprise (Papulová et al., 2014). A process approach involves the systematic identification and quality management of processes used in the enterprise and the interconnection between these processes. Nowadays, the strategic aim of any enterprise must be to achieve continuous process improvement in order to improve process performance (Cokins, 2004). Every enterprise seeks to create the best possible conditions for innovation. This is possible with two options. The enterprise can actively support innovations and not to create barriers to innovation (Čimo \& Mariaš, 2006). Innovation process is called preparation and gradual implementation of innovation changes. The innovation process results in innovation as a positive change that is being implemented and used. The task of the innovation process is to purposefully and planned influence the reproduction of the enterprise in accordance with the growing needs of the customer as well as the market as an overall system. Innovation processes in entrepreneurial activities are understood to mean the realization of certain innovations or summaries thereof, which ensure quantitative and qualitative transformation in products, processes and structure of production-technical substance with economic and social contexts (Čimo \& Mariaš, 2006). The innovation process is comprised of parts that are referred to as the stages of the innovation process. Typically, there are 5 phases of the innovation process such as science, development, research, production and use. Science includes knowledge of basic research, elaboration of theoretical approaches to solving the problem. Development includes product and thought input, product development and engineering, product design, testing and eventual product modification. Research includes applied theoretical and experimental research, and verification. Production includes production preparation, production introduction, production management, product launch and subsequent shipping. The exploitation phase includes customer service, service provision and operations as well as disposal of obsolete production, where new innovative production has been introduced. The innovation process only goes through all these stages in the case of major innovation changes. In partial innovation, it is shortened to phases that are necessary and important to ensure concrete and real innovation (Čimo \& Mariaš, 2006).

Enterprise's performance measurement can be determined using both financial and non-financial indicators. It considers financial indicators to be a traditional way of measuring performance. Nonfinancial indicators include, for example, the quality of human resources, the ability to acquire and retain customers, the quality of management. It is recommend combining traditional methods (using financial indicators) with non-financial indicators (Papulová et al., 2014). Financial performance indicators include liquidity indicators, profitability indicators, activity indicators, and indebtedness indicators (Zalai, 2016).

Process performance is a measure of achievement of desired process results, the size of which is determined by the difference between actual and desired results. The task of measuring the performance of enterprise's processes is to identify procedures that will generate objective information about the processes used in different situations and problems. It is a systematic assignment of numerical values to the appropriate sets. Measuring enterprise's process performance is a separate process of measuring work and its outputs. When measuring, it is necessary to determine the objective performance status in a chosen way or method in order to quantify the values of defined enterprise's process performance indicators. This is an opportunity for the enterprise to improve the performance of enterprise's processes. Performance, quality, and productivity are related to process performance. Quality reflects the level of ability to meet customer requirements. Productivity reflects the need for efficient use of resources. Quality and productivity directly affect performance. The relationship between these three terms is directly proportional. Improving performance will lead to increased productivity and quality improvement. Data from process performance measurements can be used to control processes. We determine performance based on production process performance indicators. Selected performance indicators of production processes include worker productivity, overall equipment efficiency, machine and process capability indexes, the proportion of non- 
conforming products to outputs, and average profit per worker (Papulová et al., 2014). Worker productivity such as performance indicator of production processes are treated in a similar way by authors Sponte Pistalu (2018) and Nica (2018). The current trend is the expansion of digitally mediated labor in technology (Mitea \& Raluca, 2018). Automated environments and breakthroughs in artificial intelligence bring about innovative kinds of skills and employment disruptions (Nica, Manole \& Stan, 2018).

\section{Data and methodology}

The object of the research is the selected Slovak producing enterprise, the predominant activity of which is development, production, recycling and application of structural plastics. It offers comprehensive plastic compounding and recycling services, including technical support. It also offers laboratory services externally. The enterprise's products are widely used in the automotive, electrical and consumer industries due to their quality and flexibility. Quality is an essential feature that enterprises' partners expect from enterprises' products. However, the enterprise offers its customers more such as care, technical service and advice that enterprises' partners get along with quality injection materials. The enterprise's know-how and flexibility make it possible to offer tailor-made products according to customer requirements and offer application technical support. It holds the following certificates: Quality Management System according to EN ISO 9001:2008, ISO/TS 16949:2009 and Environmental Management System ISO 14001:2004. The vision of the enterprise is to be a reliable, quality, flexible, stable manufacturer of structural plastics and an innovative partner for manufacturers of technical plastic moldings in Slovakia and Central Europe. The mission is to provide a comprehensive solution in the development, manufacture and supply of structural plastic for injection molding and recycling of plastic waste in collaboration with customers. It consists of headquarters and three production facilities. The headquarters is an economic, commercial, marketing and personnel center, which ensures the purchase and sale of raw materials for all production facilities. It offers technical support and services at various levels of cooperation before, during and after product delivery to customers. These services include advice and technical service from material development to production execution, comparison of equivalents, development of universal material for multiple application and technical participation in material testing. The first production facility is specialized in compounding. It has modern compounding lines to produce structural plastics for thermoplastic injection molding. The result of compounding is to create a construction plastic with the characteristics the customer requires. It produces premium plastic or recycled material, which is filled with various additives. The additives may be for example glass fiber, talc or any substance needed to achieve the properties that the customer needs. By adding these substances, the properties of the product are changed, for example the color shade is changed, the product becomes non-flammable, heat resistant, UV resistant. Thus, the customer's requirements for the product's characteristics are met. It is the largest production center, with the highest yields. Four production lines can produce 500 tons of structural plastics per month. In addition to the production of structural plastics for injection, a laboratory has been established here. For continuous product quality assurance and enhancement, it is equipped with a large testing laboratory where various types of tests are performed (physical and mechanical properties of plastics tested). The testing laboratory meets the requirements of STN EN ISO/IEC 17025:2005 and the laboratory management system meets ISO 9001:2008. The first production facility is trying to create the most suitable product directly for injection, which will be used in the second production facility. Ready-made plastic moldings are produced in the second production facility. Production in this production facility is measured in number of pieces. It has resources for injection molding. It can meet the stringent requirements of products designed especially for the automotive industry. The paper analyzes the third production facility. In the field of plastic recycling, the third production facility provides complete outsourcing of plastic waste management, thereby increasing its competitiveness and, at the same time, contributing to environmental protection. Recycled plastics are return through the regranulation process. Unusable plastic waste is purchased. It delivers the products of this facility in-house or even direct sales. The third production facility processes plastic waste, from which it produces recycles in the form of granulate. The input material for the production process is plastic waste of fibrous character, thickwalled or thin-walled plastics. The material is imported from various Slovak suppliers that 
produce plastic waste and from suppliers from abroad. The manufacturing plant buys plastic waste such as fiber, thick-walled or thin-walled plastics. These inputs must first pass through the mills (crushers). The feed material is crushed to the desired fraction to allow its regranulation. The material thus prepared is suitable for regranulation on a regranulation line. The thermal process melts the plastic waste, filters out the impurities, and is extruded into strips in the form of strings, where the strings are cooled and passed to the granulator. In the granulator, the chilled plastic strings are cut to degranulate. The resulting plastic degranulate forms the final product of the enterprise, that, after drying in the drying silo, is most often packaged in large bags of so-called big bags weighing $1000 \mathrm{~kg}$. In one day, the enterprise produces on average 3 to 3.5 big degranulate bags. The products (outputs) are used as structural plastics for injection molding of technical moldings with wide use in automotive, engineering, electrical and consumer industries. The manufacturing process consists of the receipt of material for storage, unloading of waste material, raw material input control crushing, milling of material to three kinds of mills according to the nature of the input material, transfer of crushed raw materials to the workplace of regranulation and regranulation itself, drying, packaging and weighing of the granulate, storage of finished products, the transfer of waste from workplaces to a waste warehouse, and moving finished products from stock to finished product loading area. Threads in the main production are process procurement, product development, processing orders, distribution, and customer support.

The subject of the paper is to assess the impact of process innovations on enterprise's financial performance enhancement, pointing to the necessity of implementing process innovations as fundamental aspects of measurement and enhancement of the enterprise's financial performance. Several methods of exploration were used in the paper, where epistemology was applied as a basic method of research. Standard methods of research, such as observation, synthesis, analysis, analogy, deduction, classification, and comparison presenting basic methodical approach to paper processing are applied. The knowledge gained using these research methods has created a new, higher level of knowledge of research problems. Ways of understanding and explaining impact of process innovations on enterprise's financial performance, the inductive-deductive and analytic- synthetic logical scientific methods are used. Finally, the implementation of enterprise's process innovations has a significant impact on enhancing the enterprise's financial performance, assuming optimal control and coordination of all ongoing activities in the innovation process.

\section{Results and discussion}

Production potential needs to be revealed to boost enterprise's performance. Potentials may relate, for example, to materials, processes, people, manufacturing errors, logistics, etc. We must identify the areas that will be affected by performance improvements. Increasing production performance means defining methods in three basic areas such as trial, workers and devices. The enterprise needs to know the processes thoroughly, but especially to deal with standardization and process quality. This is the key to success. Human capital is an important resource in the production process. Increasing the enterprise's performance is also dependent on employee performance. We see the greatest potential in improving performance in devices. Quality equipment of the enterprises guarantees the production of quality products and reduction of error products. Selected enterprise must monitor its performance. We will measure enterprise's performance through financial ratios and process performance indicators. We will evaluate the indicators of liquidity, activity, profitability and indebtedness of the enterprise for the period 2014-2018. We will quantify the financial indicators based on the data from the enterprise's financial statements.

Enterprise's liquidity analysis is seen as one of the most important areas, as it can draw attention to unfavorable conditions that may occur. The enterprise that achieves optimal liquidity indicators is one that can properly settle its liabilities. Liquidity ratios reflect the degree of coverage of short-term foreign funds by liquid assets. We distinguish three levels of liquidity, namely quick liquidity (recommended value 0.2-0.6), current liquidity (recommended value 1.0-1.5) and total liquidity (recommended value 2.0-2.5). We calculate the liquidity financial indicators as a ratio of current assets to liquidity and short-term liabilities. The higher the value of these indicators, the higher the probability of maintaining the enterprise's solvency. Although the values of indicators are not recommended in the literature, we evaluate the liquidity positively. The indicators have a positive trend over the last 5 years and are close to the recommended values. Based on the 
overall liquidity indicators, we can say that the enterprise is liquid, its current assets exceed the value of liabilities. Upon monetization, the enterprise can meet its short-term liabilities. In 2018, the value of current assets exceeded shortterm liabilities by more than $60 \%$. Although the balance on financial accounts is not enough to cover short-term liabilities, we may consider the enterprise to be liquid. In 2018, the current liquidity of the enterprise as already reached the recommended value, and thus, after obtaining payment of receivables from customers, the enterprise can fully cover short-term liabilities. We appreciate the increasing trend of indicators and we consider the enterprise to be liquid. The calculated liquidity indicators are shown in Table 1.

Table 1 The liquidity indicators

\begin{tabular}{l|c|c|c|c|c}
\hline Indicator/Year & $\mathbf{2 0 1 4}$ & $\mathbf{2 0 1 5}$ & $\mathbf{2 0 1 6}$ & $\mathbf{2 0 1 7}$ & $\mathbf{2 0 1 8}$ \\
\hline Quick Liquidity & 0.09257 & 0.09485 & 0.09009 & 0.09803 & 0.11618 \\
\hline Current Liquidity & 0.75244 & 0.72316 & 0.76295 & 0.89993 & 1.08238 \\
\hline Total Liquidity & 0.37364 & 1.34605 & 1.23288 & 1.44306 & 1.63246 \\
\hline
\end{tabular}

Activity indicators quantify the efficiency of enterprise's management with assets, allow us to analyze how effectively the enterprise uses it. It is a bad situation for the enterprise if has too much of an asset (extra cost, or can be covered by a loan), even a little (for example, in inventory). Typical indicators are inventory turnover time (expresses the ratio of inventories in sales), short-term receivables turnover time (expresses the ratio of receivables in sales), period of repayment of liabilities (expresses the ratio of liabilities in sales), asset turnover time (expresses the ratio of assets in sales) and asset turnover (expresses the ratio of sales in assets). Because the selected enterprise is manufacturing, it is important to monitor the inventory and turnover of inventory. Good inventory turnover has decreased significantly over the past 5 years. While in 2014 the turnover was almost 40 days, it is currently less than 25 days. A downward trend in turnover time is also expected in the future. Low inventory turnover is a sign of production continuity. At the same time, it reflects the proper management of the enterprise because the funds are not tied to inventory. Inventory turnover and the turnover of short-term receivables also decreases. Over the past 5 years, the turnover of receivables has fallen by almost half. At present, the average claim settlement time is less than 3 days. Low average time reflects the quality and stability of customers. Following the receivables turnover period, it is also necessary to assess the repayment period of short-term liabilities, which has been reduced by up to half. Currently, the short-term repayment period is less than 4 days. Based on the trend over the past 5 years, we can assume that it will continue to decline. We appreciate that the value of repayment of shortterm liabilities approximates the value of shortterm receivables turnover. At the time of collection of short-term receivables, the enterprise can settle its short-term liabilities. This fact improves the enterprise's solvency. The asset turnover period has been decreasing for 5 years and has been shorter than 1 year over the entire period. In 2018, the enterprise was able to reflect the value of its assets in sales for approximately 217 days. We appreciate very positively that the enterprise managed to turn its sales value by 1.66 times in 2018. The calculated activity indicators are shown in Table 2. 
Table 2 The activity indicators

\begin{tabular}{l|c|c|c|c|c}
\hline Indicator/Year & $\mathbf{2 0 1 4}$ & $\mathbf{2 0 1 5}$ & $\mathbf{2 0 1 6}$ & $\mathbf{2 0 1 7}$ & $\mathbf{2 0 1 8}$ \\
\hline Inventory Turnover & 39.26 & 31.55 & 27.54 & 25.87 & 24.58 \\
\hline $\begin{array}{l}\text { Short-Term } \\
\begin{array}{l}\text { Receivables Turnover } \\
\text { Time }\end{array}\end{array}$ & 5.83 & 3.21 & 3.37 & 3.22 & 2.74 \\
\hline $\begin{array}{l}\text { Period of Repayment } \\
\text { of Liabilities }\end{array}$ & 9.29 & 7.02 & 6.99 & 5.05 & 3.68 \\
\hline Asset Turnover Time & 320.03 & 276.76 & 238.66 & 267.06 & 217.43 \\
\hline Asset Turnover & 1.12 & 1.30 & 1.51 & 1.35 & 1.66 \\
\hline
\end{tabular}

Source: Own processing based on Enterprise financial statements.

Profitability indicators expresses the ratio of profit to another value characterizing the enterprise's activity (for example, sales, costs, revenues, total capital, assets, equity). When calculating profitability indicators, we consider profit after tax. The most important indicators include return on sales, cost-effectiveness, return on costs, return on capital, return on assets and return on equity. The enterprise achieves positive economic results. During the reporting period, it achieved a profit in each year. The individual indicators of profitability compare the economic result and express how much of the profit is per individual value analyzed. The most profitable components are revenues and equity. Sales are the least profitable in the enterprise. Based on profitability indicators, we consider the enterprise profitable. The calculated profitability indicators are shown in Table 3.

Table 3 The profitability indicators

\begin{tabular}{l|c|c|c|c|c}
\hline Indicator/Year & $\mathbf{2 0 1 4}$ & $\mathbf{2 0 1 5}$ & $\mathbf{2 0 1 6}$ & $\mathbf{2 0 1 7}$ & $\mathbf{2 0 1 8}$ \\
\hline Return on Sales & $25.69 \%$ & $21.68 \%$ & $25.97 \%$ & $26.26 \%$ & $24.19 \%$ \\
\hline Return on Costs & $42.13 \%$ & $37.58 \%$ & $45.00 \%$ & $46.80 \%$ & $40.92 \%$ \\
\hline Return on Revenues & $65.84 \%$ & $51.23 \%$ & $61.42 \%$ & $59.81 \%$ & $59.18 \%$ \\
\hline Return on Investments & $45.50 \%$ & $31.65 \%$ & $43.82 \%$ & $39.50 \%$ & $44.30 \%$ \\
\hline Return on Assets & $41.47 \%$ & $28.22 \%$ & $39.34 \%$ & $35.51 \%$ & $40.15 \%$ \\
\hline Return on Equity & $64.63 \%$ & $45.30 \%$ & $55.61 \%$ & $58.40 \%$ & $60.27 \%$ \\
\hline
\end{tabular}

Indebtedness indicators reflect the extent to which the enterprise is financed from its own and foreign sources. We will ensure the financial stability of the enterprise if we maintain an optimal ratio of assets coverage. In addition to monitoring the structure of financial resources, these indicators also serve to assess the enterprise's ability to repay debts. The selected indebtedness indicators are the degree of self-financing (expresses the ratio of equity in total capital), the degree of indebtedness (expresses the ratio of foreign capital in the total capital), financial leverage (expresses the ratio of assets in equity), coverage of interest (expresses the ratio of pre-tax profit and interest on total capital), interest burden (expresses the ratio of interest on pre-tax profit including interest) and insolvency (expresses the ratio of short-term liabilities on short-term receivables). Based on the indicator of the level of self-financing and the indebtedness indicator of the enterprise, the enterprise finances more than $60 \%$ of its assets from its own resources. However, it is positive that the enterprise is not highly indebted, and its interest rate is low. In 2018 , the interest rate was only $7 \%$. The resource structure is stable over the next five years. There are no significant fluctuations 
between the ratio of foreign capital and equity. The leverage ratio has been declining over the last 5 years, and thus the enterprise is reducing the value of foreign resources. Since foreign sources accounted for $33 \%$ of the total assets in 2018 , the cost of foreign capital, which is linked to the amount of interest, must also be valued. Based on the indicator of interest coverage, we can assess that the enterprise is able to pay the cost of foreign capital from the generated profit. Based on the insolvency indicator, we can also positively evaluate the ratio of short-term liabilities to shortterm receivables. The value of short-term receivables over 5 years exceeds the value of shortterm liabilities. The insolvency indicator decreases over the reporting period. Overall, we can consider enterprise is solvency. The calculated indebtedness indicators are shown in Table 4.

Table 4 The indebtedness indicators

\begin{tabular}{l|c|c|c|c|c}
\hline Indicator/Year & $\mathbf{2 0 1 4}$ & $\mathbf{2 0 1 5}$ & $\mathbf{2 0 1 6}$ & $\mathbf{2 0 1 7}$ & $\mathbf{2 0 1 8}$ \\
\hline $\begin{array}{l}\text { Degree of Self- } \\
\text { Financing }\end{array}$ & 0.64 & 0.62 & 0.71 & 0.61 & 0.67 \\
\hline $\begin{array}{l}\text { Degree of } \\
\text { Indebtedness }\end{array}$ & 0.36 & 0.38 & 0.29 & 0.39 & 0.33 \\
\hline Financial Leverage & 1.56 & 1.61 & 1.41 & 1.64 & 1.50 \\
\hline Coverage of Interest & 14.21 & 11.53 & 12.27 & 12.41 & 13.41 \\
\hline Interest Burden & 0.07 & 0.09 & 0.08 & 0.08 & 0.07 \\
\hline Insolvency & 0.97 & 0.94 & 0.94 & 0.79 & 0.72 \\
\hline
\end{tabular}

Performance indicators of production processes are labor productivity, overall equipment efficiency, machine and process capability indices, non-conformance output to output, average profitability per worker. Labor productivity is the ratio of total output to labor inputs. It is considered a general indicator of productivity; the aim of the enterprise is to maximize this indicator. For productivity analysis, it is necessary to determine the units expressing the volume of production (money or in kind), the time period for which productivity is determined (annual, monthly, daily, hour new), the number and category of workers we detect. The total output can be given in cash or in kind. This indicator determines labor productivity per employee. Factors affecting labor productivity are technology, worker qualifications, motivation, natural and climatic conditions, and work organization. The productivity of workers in the enterprise is evaluated based on the production plan. During the reporting period, the implementation of the plan reaches more than $100 \%$. The production plan was not only met but exceeded by the workers. In 2018, the plan was exceeded by $48.06 \%$. For machines we focus on the use of equipment and its downtime. For production lines, productivity measurement is a combination of machine operations and manual workstations and downtime. Based on input data, we can quantify the productivity increase potential that exists and how to achieve it at the workplace (production line). We calculate the overall device efficiency as a product of availability, performance, and quality indicators. Availability expresses the ratio of values in the numerator the difference between the planned production time of the planned downtime and the unplanned downtime and in the denominator the value of the planned production time. The performance expresses the proportion of values in the numerator of the product of the production cycle and the number of pieces produced in the denominator the difference between the planned production time and the planned downtimes. Quality expresses the ratio of the values in the numerator the difference between the number of good pieces produced and the number of failures and the denominator of the total number of pieces. The ratio of noncommodities in outputs expresses the proportion of the number of non-commissions and total outputs. There are negative factors in the enterprise that affect production, such as downtime, material waiting, unskilled workers, production of junk, machine failures. The overall device efficiency of the enterprise is positive and reaches a relatively high value compared to the world class in this area, which is around $85 \%$. The overall efficiency of the device increased to $89 \%$ in 2018 . In the period under review, the enterprise managed to keep the ratio of offsets to total outlets close to zero, which means that they record a minimum of product failures and product claims. 


\section{Conclusion}

Innovation in manufacturing processes in the enterprise leads to increased machine and employee productivity, and consequently to increased overall enterprise's performance and improved financial and economic indicators. The aim of the paper was to analyze enterprise's process innovations in the context of enterprise's financial performance enhancement and to assess opportunities to develop these processes as fundamental aspects of measurement and enhancement of the enterprise's financial performance. Based on the analyzed data, we evaluate the positive financial performance and performance of the process. The enterprise achieves positive results in the area of financial indicators and the stability and performance of the production process. The significant innovation of the selected enterprise is monitoring whether process performance increases or decreases over the previous year and predicts trends next year.

Based on the observation of the current state of processes in the enterprise, we recommend introducing innovation in the field of marketing strategy. Innovation is about emphasizing the ecological character of the enterprise in the context of the established environmental management system in the enterprise. Such an innovation of marketing strategy and communication would also correspond to the current trend of the enterprise and the constantly growing emphasis on the positive impact of enterprises on the environment. Based on the research results, we can state that the implementation of enterprise's process innovations has a significant impact on enhancing the enterprise's financial performance, assuming optimal control and coordination of all ongoing activities in the innovation process.sm

\section{References}

Borovský, J. (2005). Manažment zmien - cesta k rastu konkurencieschopnosti. Bratislava: Eurounion.

Cokins, G. (2004). Performance Management - finding the missing pieces. New Jersey: John Wiley \& Sons.

Drucker, P. F. (2007). Innovation and entrepreneurship: practice and principles. Oxford: Elsevier ButterworthHeinemann.

Čimo, J., \& Mariaš, M. (2006). Inovačný manažment. Bratislava: Cicero.

Dugas, J., \& Ferencz, V. (2015). Manažérstvo inovácií. Bratislava: Ekonóm.
Freeman, CH. (2008). Systems of innovation: selected essays in evolutionary economics. Cheltenham: Edward Elgar.

Germani, M., Luzi, A., Marilungo, E., Papetti, A., \& Peruzzini, M. (2016). Investigating the sustainability of a high-energy consuming industrial process to achieve total quality. International Journal of Productivity and Quality Management, 18 (2-3), 301-324. https://doi.org/10.1504/IJPQM.2016.076712

Chan Kim, W., \& Mauborgne, R. (2015). Blue Ocean Strategy. Boston: Harvard Business Review Press.

Kislingerová, E. et al. (2008). Inovace nástrojů ekonomiky a managementu organizací. Praha: Beck.

Lesáková, L'. (2008). Inovatívny manažment vo vedomostnej ekonomike. Banská Bystrica: Univerzita Mateja Bela.

Liu, L., \& Jiang, Z. (2016). Influence of technological innovation capabilities on product competitiveness. Industrial Management and Data Systems, 116 (5), 883-892.

https://doi.org/10.1108/IMDS-05-2015-0189

Mitea, D., \& Raluca E. (2018). The expansion of digitally mediated labor: platform-based economy, technologydriven shifts in employment, and the novel modes of service work. Journal of Self-Governance and Management Economics, 6 (4), 7-13. https://doi.org/10.22381/JSME6420181

Nica, E. (2018). Gig-based working arrangements: business patterns, labor-management pactices, and regulations. Economics, Management, and Financial Markets, 13 (1), 100-105. https://doi.org/10.22381/EMFM13120185

Nica, E., Manole, C., \& Stan, C. I. (2018). A laborless society? How highly automated environments and breakthroughs in artificial intelligence bring about innovative kinds of skills and employment disruptions, altering the nature of business process and affecting the path of economic growth. Journal of SelfGovernance and Management Economics, 6 (4), 2530. https://doi.org/10.22381/JSME6420184

Papulová, Z., Papula, J., \& Oborilová, A. (2014). Procesný manažment. Bratislava: Kartprint.

Schumpeter, J., \& Swedbeg, R. (1989). Essays: On Entrepreneurs, Innovations, Business Cycles, and the Evolution of Capitalism. New Brunswick: Transaction Publ.

Sponte Piştalu, M. (2018). Cognitive Performance and Labor Market Outcomes: Evidence from the U.S. Economics, Management, and Financial Markets, 13 (2), 70-75. https://doi.org/10.22381/EMFM13220185

Synek, M. (1996). Manažerská ekonomika. Praha: Grada Publishing.

Zalai, K. (2016). Finančno-ekonomická analýza podniku. Bratislava: Sprint. 


\section{$\triangle$ Correspondence}

\section{Marianna Kicová}

University of Economics in Bratislava

Faculty of Economic Informatics

Dolnozemská cesta 1, 852 35, Bratislava, Slovakia

E-mail: marianna.kicova@euba.sk 